\title{
Correlation of Fischer's Ratio with Liver Fibrosis in Naive Chronic Hepatitis B Patients without Comorbidities
}

\author{
Mohammad Rilwanu Rafsanjani ${ }^{1 *}$, Triyanta Yuli Pramana ${ }^{2}$, Arifin $^{3}$ \\ ${ }^{1}$ Resident of Internal Medicine, Sebelas Maret University \\ Surakarta, Indonesia \\ ${ }^{2}$ Departement of Internal Medicine, Gastro Entero, Hepatology Subdivision, Sebelas Maret University \\ Surakarta, Indonesia \\ ${ }^{3}$ Departement of Internal Medicine, Infection Subdivision, Sebelas Maret University \\ Surakarta, Indonesia \\ ${ }^{*}$ Corresponding author's email: namakuican [AT] gmail.com
}

\begin{abstract}
---
Introduction:

Hepatitis $B$ virus infection is one of the most common health problems in the world. $20 \%$ Chronic hepatitis $B$ can can change into liver fibrosis. The liver is the center of the body's Amino Acids metabolism. Amino acid changes can occur due to impaired liver function. Fisher's ratio (BCAA/AAA) has become one of the sign of liver fibrosis. This study wanted to find a relationship between Fischer Ratio values and liver fibrosis in naive chronic hepatitis B patients without comorbidities.
\end{abstract}

Method:

The research was conducted from October 2020-May 2021 at DR. Moewardi Hospital, Surakarta, Indonesia. Subjects were naive chronic hepatitis $B$ patients without comorbidities with a minimum age of 30 years. The study used a crosssectional method. Fischer Ratio values were assessed by spectrophotometry and liver fibrosis was assessed by transient elastography (fibroscan). A correlation test was conducted to determine the relationship between variables.

Result:

20 patients were included in the study. The average age of the research subjects was $47 \pm 10$ years. The average Fisher's ratio value was $2.83 \pm 1.16$ and the average fibroscan value was $17.31 \pm 18.50 \mathrm{kPa}$. Ratio Fischer had a correlation with liver fibrosis with $r=-0.571(p=0.004)$.

Conclusions:

Ratio Fischer has a negative correlation with liver fibrosis in naive chronic hepatitis $B$ patients without comorbidities.

Keywords--- Hepatitis B, Fisher's ratio, Liver Fibrosis

\section{INTRODUCTION}

Hepatitis B virus infection is still a health problem in the world. It is estimated that one third of this world population has been contaminated by Hepatitis B Virus. The prevalence of Hepatitis B Virus Patient in Indonesia is estimated Between $4.0-20.3 \%(1,2)$. Chronic hepatitis B patients without therapy has happened to $8-20 \%$ patient, which $20 \%$ from this group could progressed into cirrhosis (3).

The liver is the largest organ and the main metabolic center in the body, investigating the signs of metabolic changes is very promising in the search for new biomarkers and therapeutic targets (4). Comparison between Branched Chain Amino Acid (BCAA) and Aromatic Amino Acid (AAA) or Fisher's ratio is generally known to change in patients with cirrhosis of the liver. The decrease in Fisher's ratio could be found in the cirrhosis patient (5).

In this study, we will look at whether Fisher's ratio is associated with liver fibrosis in naive chronic hepatitis B patients without comorbidities. Knowing early signs of liver damage by amino acids profile is expected to increase the survival of patients with chronic hepatitis B infection. 


\section{METHODS}

This study conducted at DR. Moewardi Hospital, Surakarta, Indonesia Patients who met the criteria were included in the study in the period October 2020 - May 2021. Cross sectional method was used.

Patients aged at least 30 years who were diagnosed with chronic hepatitis B as evidenced by reactive $\mathrm{HBs} \mathrm{Ag}$ and had no history of therapy were included in the study. Patients were excluded if they were co-infected with Hepatitis C and HIV, had decompensated hepatic cirrhosis, had hepatocellular carcinoma or other malignancies, had biliary system disease, had a BMI $>25 \mathrm{~kg} / \mathrm{m} 2$ or $<18.5 \mathrm{~kg} / \mathrm{m} 2$, had a history of alcohol consumption, had diabetes other chronic conditions other than hepatitis B, and were not willing to participate in the study. All subjects who meet the criteria are included in the study until the specified time limit.

Ratio Fischer value is the ratio between BCAA which consists of valine, leucine, and isoleucine compared to AAA which consists of phenylalanine, tryptophan and tyrosine. Amino acids were examined using a spectrophotometric method from the patient's plasma after fasting for at least 8 hours. The fibrosis value was assessed using transient elastography (fibroscan) in $\mathrm{kPa}$ units. The degree of fibrosis F0-F1 was concluded if the fibroscan value was below $7.2 \mathrm{kPa}$, the degree of fibrosis was F2 if the fibroscan value was $\geq 7.2 \mathrm{kPa}$, the degree of fibrosis was F3 if the value was $\geq 10.5 \mathrm{kPa}$, and the degree of fibrosis was F4 if the value was $182 \mathrm{kPa}(6)$. Secondary data such as platelet count, creatinine, ALT, AST, $\mathrm{HBeAg}$, and HBV DNA in the study were taken from medical record data.

Quantitative variables with normal distribution were tested by ANOVA/F test, quantitative variables with abnormal distribution were tested by Kruskal-Wallis, and qualitative variables were tested by Chi Square test. Shapiro Wilk test is used to determine whether the data is normally distributed. The Pearson correlation test was used to assess the correlation of Ratio Fischer with liver fibrosis when the data distribution was normal, and the Spearman correlation test was used when the data distribution was not normal. All calculations using SPSS v.22.

This study received ethical clearance from the Health Research Ethics Commission of Dr. Moewardi Hospital with the number: 1.101/ IX/ HREC/ 2020.

\section{RESULT}

20 patients were consisting of $55 \%$ men and $45 \%$ women. The mean age of the subjects was $47 \pm 10$ years. There were $30 \%$ of the patients who had fibrosis degrees F0-F1, 25\% F2, 20\% F3, and 25\% F4. The characteristics of the subject variables can be seen in table 1. There was no significant difference in the variable characteristics of the research subjects based on the degree of fibrosis.

Table 1 Description and Results of Variable Analysis of Subject Characteristics Based on the Category of Fibrosis Degree

\begin{tabular}{|c|c|c|c|c|c|c|}
\hline \multirow{2}{*}{ Variable } & \multicolumn{4}{|c|}{ Fibrosis Degree } & \multicolumn{2}{|c|}{ Statistic Test } \\
\hline & F0-F1 & F2 & F3 & F4 & $\mathrm{F} / \mathrm{X}^{2}$ & $P$ value \\
\hline Age $(\text { years })^{1}$ & $48 \pm 9$ & $47 \pm 14$ & $48 \pm 9$ & $48 \pm 10$ & 0,502 & 0,984 \\
\hline Sex: ${ }^{3}$ & & & & & 1,818 & 0,611 \\
\hline \multirow{2}{*}{$\begin{array}{ll}\text { - } & \text { Male } \\
\text { - } & \text { Female }\end{array}$} & $3(50,00)$ & $2(40,00)$ & $2(50,00)$ & $4(80,00)$ & & \\
\hline & $3(50,00)$ & $3(60,00)$ & $2(50,00)$ & $1(20,00)$ & & \\
\hline Platelet $\left(10^{3} / \mathrm{ul}\right)^{1}$ & $\begin{array}{l}240,33 \pm \\
9,05\end{array}$ & $244,40 \pm 12,12$ & $236,75 \pm 24,73$ & $198,60 \pm 49,82$ & 2,838 & 0,071 \\
\hline Creatinine $(\mathrm{mg} / \mathrm{dl})^{1}$ & $0,83 \pm 0,14$ & $1,01 \pm 0,15$ & $0,88 \pm 0,18$ & $0,84 \pm 0,17$ & 1,373 & 0,287 \\
\hline $\operatorname{ALT}(\mathrm{u} / \mathrm{l})^{1}$ & $\begin{array}{l}18,33 \pm \\
8,07\end{array}$ & $19,40 \pm 5,73$ & $22,25 \pm 3,50$ & $32,80 \pm 21,66$ & 1,525 & 0,246 \\
\hline
\end{tabular}




\begin{tabular}{|l|l|l|l|l|l|l|}
\hline AST $(\mathrm{u} / \mathrm{l})^{2}$ & $18,33 \pm 8,73$ & $22,60 \pm 4,28$ & $23,25 \pm 2,50$ & $41,20 \pm 31,73$ & 4,179 & 0,243 \\
\hline $\begin{array}{c}\text { HBeAg: }{ }^{3} \\
-\quad \begin{array}{l}\text { Negative } \\
-\quad \text { Positive }\end{array}\end{array}$ & $\begin{array}{l}4(66,70) \\
2(33,30)\end{array}$ & $\begin{array}{l}2(40,00) \\
3(60,00)\end{array}$ & $\begin{array}{l}4(100,0) \\
0,00\end{array}$ & $\begin{array}{l}4(80,00) \\
1(20,00)\end{array}$ & 4,127 & 0,248 \\
\hline HBV-DNA (IU/ml) & $\begin{array}{l}2080,33 \\
2414,77 \text { million }\end{array}$ & $\begin{array}{l}12,96 \pm 15,37 \\
\text { million }\end{array}$ & $\begin{array}{l}17,81 \pm 12,35 \\
\text { million }\end{array}$ & $\begin{array}{l}15,61 \pm 10,53 \\
\text { million }\end{array}$ & 2,991 & 0,062 \\
\hline
\end{tabular}

Note: *Significant at a significance level of 5 percent $(\mathrm{P}<0.05)$

$* *$ Significant at a significance level of 1 percent $(\mathrm{p}<0.01)$.

${ }_{1}$ Quantitative variables with normal distribution were tested by ANOVA/F test with F test statistic.

${ }_{2}$ Quantitative variables with abnormal distribution were tested by Kruskal-Wallis test with X2 test statistic.

${ }_{3}$ Qualitative variables with Chi Square test with X2 test statistic.

To see the difference in the average Fischer Ratio value based on the degree of fibrosis, an ANOVA test was carried out, the following results were obtained:

Table 2 Description and Results of ANOVA Variable BTR, and Fibrosis Value

\begin{tabular}{lllllll}
\hline \multirow{2}{*}{ Variable } & \multicolumn{2}{l}{ Fibrosis Degree } & \multicolumn{3}{l}{ Statistic test } \\
\cline { 2 - 7 } & F0-F1 & F2 & F3 & F4 & F & P value \\
\hline \multirow{2}{*}{ BTR } & $3,43 \pm$ & $3,49 \pm$ & $2,47 \pm$ & $1,73 \pm$ & \multirow{2}{*}{3,995} & \multirow{2}{*}{$0,027^{* *}$} \\
\hline
\end{tabular}

Keterangan : *Significant at a significance level of 5 percent $(\mathrm{P}<0.05)$

$* *$ Significant at a significance level of 1 percent $(\mathrm{p}<0.01)$.

To find the correlation between Fisher's ratio and fibrosis, the Pearson correlation test was carried out after it was stated that the data were normally distributed using the Shapiro Wilk test. Based on the results of the correlation test Fisher's ratio has a negative correlation with liver fibrosis with a value of $r=-0.571$ and $p=0.004$.

\section{DISCUSSION}

The Fisher's ratio value was lower with increasing fibrosis, in this study a negative correlation was found with $\mathrm{r}=-0.571$ and $\mathrm{p}=0.004$ values. The average Fisher's ratio value for $\mathrm{F} 2$ was $3,49 \pm 1,19$ and for F4 was $1,73 \pm 0,65$. The term of significant fibrosis defined when fibroscan above $7.2 \mathrm{kPa}$ or $\geq \mathrm{F} 2$ (7).

A previous study in China on 147 patients with liver cirrhosis without amino acids therapy various etiologies including hepatitis B showed a significant relationship between Fischer's ratio, BTR values and Hepatitis B patient. When compared with the control group (HDs), the concentration of AAA and Tyr from patients with HBV infection showed significant differences ( $\mathrm{p}<0.05$ or 0.01 ), with the exception of the CHB-m group ( $\mathrm{p}>0.05)$. Furthermore, a significant decrease ( $\mathrm{p}<0.05$ or 0.01) was recorded when the BCAA concentration, the BCAA/AAA ratio, and the BTR from patients with various clinical stages of HBV infection (AHB, CHB-m, CHB-h, LC, and CSHB) were compared with those of the HD group. Moreover, the BCAA/AAA ratio and the BTR were most significantly decreased in the CSHB group ( $<<0.001)(8)$.

In liver damage, catabolism occurs in peripheral tissues, $30-40 \%$ of the body's energy is obtained through BCAA oxidation and gluconeogenesis. The use of BCAAs will cause a decrease in BCAA levels in the blood if the intake is not good (9). Loss of hepatocytes will cause an increase in ammonia metabolism in muscles and cause the use of BCAAs to convert ammonia and glutamate to glutamine to increase (10). Both of these things can lower BCAA levels.

Impaired metabolism of AAA in liver damage also occurs. Proteolysis increases phenylalanine levels and increased hydroxylation of phenylalanine outside liver cells causes tyrosine levels to increase. The reduced clearance of amino acids in the splanchnic space also causes an increase in tyrosine levels (11).

From the explanation above, it can be concluded that in conditions of chronic liver disease, BCAA levels will decrease along with the progression of liver disease.

BCAAs will enter the cytosol and are converted by the branched-chain amino acid aminotransferase (BCAT) enzyme to become compounds that can enter the mitochondria and have a role in the energy formation process through the tricarboxylic acid (TCA) cycle (12). Tyrosine will undergo catabolism into acetoacetate which will then enter the TCA cycle to produce adenosine triphosphate (ATP) (11). Under conditions of liver cell damage, the formation of tyrosine from phenylalanine in liver cells will decrease (9). In chronic hepatitis B, mitochondrial dysfunction also occurs, the low functional ability of cyclooxygenase III (COX III) blocks proton transfer and causes the accumulation of electrons and 
oxygen molecules so that ATP synthesis is reduced and reactive oxygen species (ROS) production is increased. The absence of ATP increases hepatocyte apoptosis (13). From this description, it is possible to conclude that the reduced hepatocyte ATP formation due to low BCAA levels and reduced tyrosine production due to reduced phenylalanine hydroxylation in the liver can exacerbate mitochondrial dysfunction that has already occurred so that the speed of hepatocyte apoptosis can increase.

Our study has several limitations. This study has a small sample size so that the power of the study is not large, some data are taken only based on medical records so secondary data may be missing.

In conclusion, this study shows that there has been a decrease in Fischer's Ratio in chronic hepatitis B patients even though the patient has not been diagnosed with decompensated hepatic cirrhosis, this finding can be the basis for other studies that want to use Fischer's Ratio as a predictor of early fibrosis or as a therapeutic target to slow disease progression in chronic hepatitis B patients.

\section{ACKNOWLEDGMENTS}

We thank all Internal Medicine Resident, Sebelas Maret University, for the effort to gather data.

\section{REFERENCES}

1. Huang DQ, Lim SG. Hepatitis B: Who to treat? A critical review of international guidelines. Liver Int. 2020 Feb;40(S1):5-14.

2. Asdie AH, Wiyono P, Rahardjo P. Harrison Prinsip-prinsip ilmu penyakit dalam. Jakarta: EGC; 2012.

3. Parikh P, Ryan JD, Tsochatzis EA. Fibrosis assessment in patients with chronic hepatitis B virus (HBV) infection. Ann Transl Med. 2017 Feb;5(3):40-40.

4. Chang M-L, Yang S-S. Metabolic Signature of Hepatic Fibrosis: From Individual Pathways to Systems Biology. Cells. 2019 Nov 12;8(11):1423.

5. Enomoto H, Sakai Y, Aizawa N, Iwata Y, Tanaka H, Ikeda N, et al. Association of amino acid imbalance with the severity of liver fibrosis and esophageal varices. Annals of Hepatology. 2013 May;12(3):471-8.

6. de Lédinghen V, Vergniol J. Transient elastography for the diagnosis of liver fibrosis. Expert Review of Medical Devices. 2010 Nov;7(6):811-23.

7. Satyadi ., Nusi IA, Setiawan PB, Purbayu H, Sugihartono T, Maimunah U, et al. Transient Elastography as NonInvasive Examination of Hepatic Fibrosis: In: Proceedings of Surabaya International Physiology Seminar [Internet]. Jawa Timur, Indonesia: SCITEPRESS - Science and Technology Publications; 2017 [cited 2020 Aug 22]. p. 426-30. Available from: http://www.scitepress.org/DigitalLibrary/Link.aspx?doi=10.5220/0007340104260430

8. Ishikawa T, Imai M, Ko M, Sato H, Nozawa Y, Sano T, et al. Correlation between plasma amino acid profiles and the various stages of hepatitis B infection. 2012 Febt 31:2045-52.

9. Nefyodov II, Karakosh AJ, Alufaini MA, Karavay PA, Karavay NL. Amino Acids and their Derivatives in Pathogenesis and Treatment of Liver Diseases. Grubovic RM, editor. JHOR. 2019 Dec 4;3(3):1-8.

10. Wright G, Noiret L, Olde Damink SWM, Jalan R. Interorgan ammonia metabolism in liver failure: the basis of current and future therapies: Interorgan ammonia metabolism in liver failure. Liver International. 2011 Feb;31(2):163-75.

11. Tessari P, Vettore M, Millioni R, Puricelli L, Orlando R. Effect of liver cirrhosis on phenylalanine and tyrosine metabolism: Current Opinion in Clinical Nutrition and Metabolic Care. 2010 Jan;13(1):81-6.

12. Aliu E, Kanungo S, Arnold GL. Amino acid disorders. Ann Transl Med. 2018 Dec;6(24):471-471.

13. Ling L, Zheng D, Zhang Z, Xie W, Huang Y, Chen Z, et al. Effect of HBx on inflammation and mitochondrial oxidative stress in mouse hepatocytes. Oncol Lett [Internet]. 2020 Feb 17 [cited 2020 Jul 11]; Available from: http://www.spandidos-publications.com/10.3892/ol.2020.11404 